\title{
Study of Architectural Ceramics of the Qal'a of Bani Hammad
}

\author{
Brahmi A*, Hamiane M \\ Materials, Processes and Environment Research Unit (MPE-RU), city Frantz Fanon 35000 Boumerdes, \\ Algeria \\ * Corresponding Author: abla arch@yahoo.fr
}

Received: 25-02-2018

Revised: 04-06-2018

Accepted: 13-06-2018

\begin{abstract}
In order to define with precision, the physicochemical characteristics of the architectural ceramic exhumed from the Qal'a of Bani Hammad's site (inscribed on the UNESCO's World Heritage List in 1980), our study was conducted on a set of ceramics. The first analyses were focused on the color of the glazes, by optical absorption spectrophotometry (also called optical absorbance spectroscopy), on the texture by X-Ray diffraction, and on the elemental composition of the various constituent stages of these glazes and their terra cotta, by scanning electron microscopy and X-Ray fluorescence. Indeed, the study combining optical absorbance spectroscopy and X-Ray fluorescence enabled us to determine the origin of the monochromic green coloring of the glazes in some samples. This coloring can be attributed to the presence of the $\mathrm{Cu}^{2+}$ chemical element; but these glazes darkened due to the high iron content they contain. This could be explained by an intentional addition of iron, in tin-opacified leaded glazes, baked in an oxidizing atmosphere and put on a limestone-rich marlacious paste.

The chemical and mineralogical analyses of all shards show that their paste is calcareous. This dataset will be exploitable for re-creation experiments. It also represents a first exploitable referential system, for potential comparisons with other samples belonging to other Algerian sites and different periods of time.
\end{abstract}

Key words: The Qal'a of Bani Hammad; physicochemical characterization of ceramics; optical absorption spectrometry; X-ray fluorescence; X-ray diffraction.

\section{Introduction}

An Ifriqiyan architecture took shape in the $9^{\text {th }}$ century and the first elements of a ceramic art appeared in Kairouan under the Aghlabids dynasty. Moreover, important urban centers such as Mahdia, the Qal'a of Bani Hammad, Bougie, Tunis, appeared and adopted this new industry.

As for the Qal'a of Bani Hammad, numerous records confirm that it was one of the most dynamic cultural and scientific centers of central Maghreb in the $11^{\text {th }}$ and $12^{\text {th }}$ century. It played an important role of "relay place" after the decline of Kairouan and before the founding of Bougie (Aissani and Amara, 2014); and there is no doubt that local workshops definitely existed. Golvin (1978) even assumed their exact location at the Qal'a of Bani Hammad. The ceramic that we found in this site has an oriental style and continues the Egyptian Aghlabid and Fatimid tradition (Daoulatli, 1978). More specifically, the architectural ceramic is abundantly represented in the Qal'a; the remarkable variety of its production techniques can only stir up regrets, regarding the fact that no systematic study using modern analysis processes has been undertaken, despite promising typological rating tests carried out a long time ago by George Marçais (Golvin, 1978) and refined by other archaeologists.

Although the site perfectly meets the criterion of authenticity defined by the world heritage chart, we defined specific objectives for this study by not selecting "all" the architectural ceramic varieties existing in the Qal'a. Indeed, the purpose of this work is to expose some varieties of the ceramic exhibited in our different museums, to provide a counterpoint regarding the analyzed 
ceramics and to contribute, on the first part, to the collection of analytical data supposed to promote historical, archaeological and architectural research, with a focus on the production techniques of the ceramics in question, as well as their diffusion and movement.

\section{Sampling and Analytical Methods}

A first study of the ceramic (collected from the Qal'a of Bani Hammad's site) took place in 1903 in works dedicated to the old city. It was led by A. Roberto, who provided the reproduction of nine shards, among which eight were in color and mentioned them in the "Collection of the Archaeological Society of Constantine". In 1906, Georges Marçais emphasized on the importance of this ceramic, in a comprehensive study on Art in Algeria. In 1908, M. Saladin published and commented on Paul Blanchet's notes, evoking architectural coatings and ceramic partitions found in the ruins. In 1909, General De Bey lié put forward in his book on the Qal'a, pictures and engraved drawings, and summarily analyzed this industry.

In 1965, Lucien Golvin provided in his book « Archaeological Research at the Qal'a of the Bani Hammad", pictures and drawings of an important amount of ceramic, exhumed from the site in question. He also gave a descriptive approach on the production techniques used in the past. This same year 1965, Rachid Bourouiba published in a preliminary report about the excavations campaign led by himself, a number of plates about architectural ceramic and ordinary potteries exhumed from these excavations, that took place in September 1964.

Besides, seven samples of the architectural ceramic, used for the construction and the interior and exterior decoration of the Qal'a's palaces, were selected for this study. A quick examination of the physical characteristics of these samples enabled us to choose the appropriate investigation methods to solve the problem and, to define the analytical modes. These samples were submitted to the following tests:

First, the surface of each shard was photographed and observed thanks to a binocular magnifier. Then, millimetric chips removed from each shard were examined by using a scanning electron microscopy (PHILIPS.SEM 505 model).

In order to identify the chromogen agents responsible for the coloring of the glazes, at the level of the enameled samples, adouble-ray UV-visible optical absorption spectrometer (CARY 500 de Varian model) was used with the spread-reflection mode, directly on the sample for the glaze and in section for the terra cotta; the scanned spectral range vary between $350 \mathrm{~mm}$ and $800 \mathrm{~mm}$.

The study of the glaze's elementary composition was performed by using the backscattering electron mode, thanks to the X-Ray fluorescence paired up with the scattering energy scanning electron microscopy (JEOL JSM6360LV model). Results are in oxides mass percentage and the measures were carried out on cross-sections of glazes, previously polished and metallized with a thin carbon layer, on selected areas.

The study of the terra cotta's elementary composition was performed with an X-fluorescence spectrometer (SRS 3400 - BRUKER - AXS model). Results are in oxides mass percentage and the measures were carried out on pearls, with a small amount of terra cotta.

The study of the terra cotta's mineralogical composition was performed with an X-ray diffractometer (PANalytical: XPERT-PRO model).

During the surface collection, the KBHEC01 sample was found at the level of the Lake palace, and KBHEC06 was also collected from a ground paving made of terra cotta bricks; the whole of the bricks was put in opus picatum at the level of this same palace. Nevertheless, the KBHEC05, KBHEC08, KBHEC09, KBHEC10 and KBHEC12 samples were collected at the level of the Manar palace. 


\subsection{Presentation of the studied material}

The KBHEC01 sample: it represents a stalactite debris molded and enameled in opaque white on the four faces; the terra cotta is beige orange, compact and contains some thin and abundant inclusions. The piece has a parallelepipoid shape with four levels; on each side, we notice ribs.

The KBHEC05 sample: this one is a fragment from a rounded tile, produced by the modelling technique; the terra cotta is red-rosy, compact and contains a thick and abundant grog grease remover.

The KBHEC06 sample: It is a brick, produced by using the modelling technique, with a red color, compact and it contains a thick and abundant grog grease remover.

The KBHEC08 sample: it is a merlon debris molded in a leaf shape, which low surface is enameled in a dull green that has almost all disappeared. The paste of this shard is beige yellow, compact and contains some thick and abundant inclusions. This merlon represented a frieze element that decorated the Hammadid palaces' frontage.

The KBHEC09 sample: It presents a six-point star-shaped ceramic marquetery, molded and enameled in a bottle-green color on its superior surface. The paste of this marquetery is redrosy.

The KBHEC10 sample: this one is a fragment from a cross-shaped marquetery, used as ground paving, molded and enameled in white on its superior surface. The paste of this marquetery is beige yellow, compact and it contains some very thin and abundant inclusions.

The KBHEC12 sample: it represents a triangle-shaped ceramic marquetery debris, molded and enameled in green on its superior surface. The paste of this marquetery is beige yellow, compact and contains some very thin and abundant inclusions.

All the samples indicated above are dated given the current state of knowledge, between the $5^{\text {th }}$ and $6^{\text {th }}$ Hijri century $\left(11^{\text {th }}-12^{\text {th }}\right.$ century after J.C).

\section{Experimental results and Discussion}

\subsection{Study of the surface's states}

To the naked eye and by using the binocular magnifier, we notice that the surface state of these samples is characterized by a more or less significant loss of color. All these surfaces have some scratches caused by a mechanical degradation. One of the samples, KBHEC10, also exhibited a "crazing". These cracks emerge in the glaze during the cooling, comingfrom traction pressures due to differences in terms ofthermal distention coefficient between the ceramic paste and the glaze. It is not uncommon to observe them on the surface of a glaze (Munier, 1957). All samples appear to be in good condition. They all have relatively homogeneous surfaces. With the exception of the KBHEC08 sample, which almostlost all of its green glaze; the remaining part appears in a more advanced state of degradation.

Macroscopically, KBHEC01 presents on its glazed part a defect of withdrawal. In the current state of knowledge, the glaze withdraws from the shard during the fusion and reveals spots where the clay is bared (Fig. 1). This phenomenon can affect a glaze put on a poorly dusted biscuit. Moreover, a frequent cause of this phenomenon is the crazing and cracking of the raw glaze. This case is more frequent in very matt glazes and viscous glazes during the fusion (Rhodes, 1976).

On a fresh break at the level of the terra cotta contained in the KBHEC09 sample, we observe the presence of undecomposed limestone or gypsum in the shard's pores (Fig. 2). The observation under the binocular magnifier of a polished section at the level of the interface zone, between the glaze and the terra cotta support of the same sample, reveals the presence of a yellow border 
(strip) (Fig. 3),particularly visible at the level of the green glaze; which could correspond to devitrification crystals. This leads us to assume that the glaze was put on earth.

At the level of the KBHEC10's terra cotta and on a polished section (fig. 4), the paste presents a beige color; it contains mauve luminescent grains, surrounded by a large amount of orange grains. This color could correspond to the respective presence of quartz crystals and undissolved calcite. The observation under the magnifier, at the level of the terra cotta contained in the KBHEC12 sample reveals characteristics similar to those contained in the previous sample: the beige terra cotta contains mauve luminescent grains, surrounded by a large amount of orange grains. At this scale, no other characteristic is discernible.

The observation using the backscattering electron mode shows the heterogeneity of the glaze contained in the KBHEC08 sample, its thickness of about $350 \mu \mathrm{m}$ (fig. 5) as well as the presence of numerous variable-size bubbles. The bubbles were probably formed during the degassing phase of the terra cotta, or during the decomposition if the glazed mix during the baking. Besides, KHBEC12 (fig 6) reveals on its glazed surface tiny needles, which could represent residues coming from a vegetal ash or from a contamination of the environment, such as biological microorganisms.

\subsection{Caracteristics of the glazes}

\subsubsection{Measure of the glazes color}

The physicochemical origin of the coloring of the glaze is accessible analytically, by trying to identify metallic cations playing the role of chromogen agents. The registered optical absorption spectrum can thus be compared with reference absorption spectra.

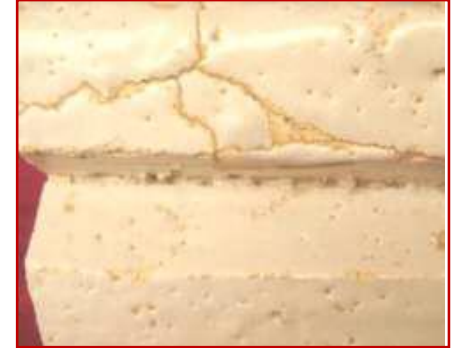

Fig. 1. Defect of withdrawal of the stalactite enamel KBHEC01

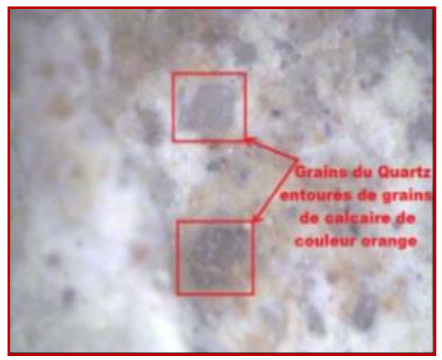

Fig. 4 . Polished section at the level of the paste of KBHEC10

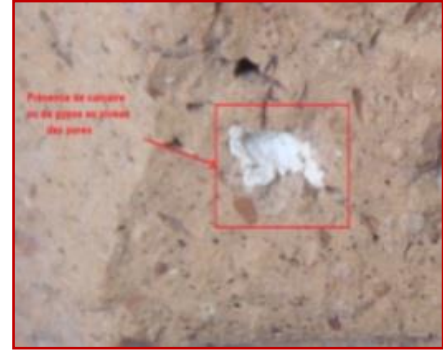

Fig. 2. Observation on a fresh break at the level of the terra cotta, KBHEC09

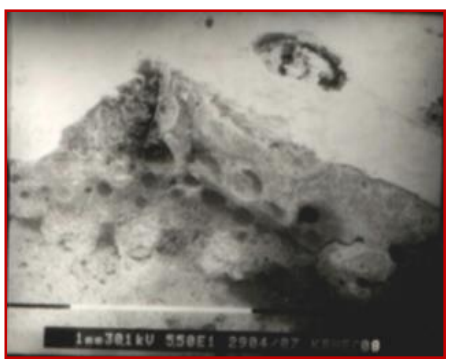

Fig. 5 . Micrography using the MEB of the glaze/terra cotta interface zone of KBHEC08

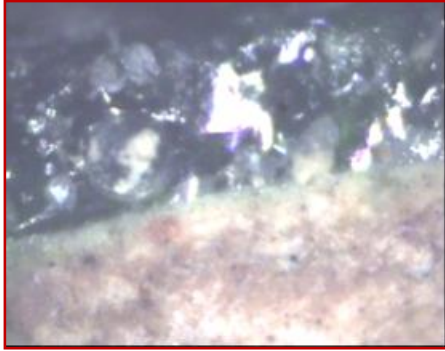

Fig. 3 . The glaze/terra cotta interface zone, KBHEC09

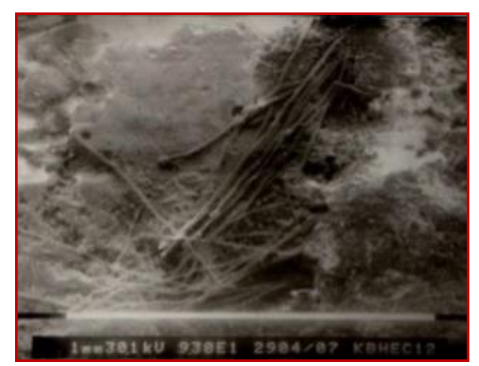

Fig. 6 . Micrography using the MEB of the glazed surface of KBHEC12

The spectra obtained on the white glaze contained in KBHEC01 and KHBEC10 respectively present a low absorption between 350 and $410 \mathrm{~nm}$ and between 350 and $450 \mathrm{~nm}$, which corresponds to the violet area. Afterwards, the absorption is very low and constant between 450 
and $800 \mathrm{~nm}$. The spectra show that the obtained color is not a perfect white but an off-white; and this, due to the absorption in the violets, as well as the beginning of the blues present in the glazes of the two samples. These spectra do not allow us to reveal the chromogen elements responsible for the coloring (Richard, 2000).

The optical absorption spectra of the KHBEC08, 09 and 12 show a first absorption strip between 350 and 500 to $520 \mathrm{~nm}$ (corresponding to the visible and blues area), and a second starting from $550 \mathrm{~nm}$. A large strip varying from 550 and $800 \mathrm{~nm}$ is normally attributed to the $\mathrm{Cu}^{2+}$, which gives the glaze a green color when it gets leaded (Rhodes, 1976).

\subsubsection{Elementary composition of the glazes}

For the white glazes contained in the KBHEC01 and KBHEC10 samples, they represent potassic alkaline-leaded glazes (Table 1 ), which white opaque aspect is essentially due to the presence of tin $\left(\mathrm{SnO}_{2}=10.95 \pm 1.58\right.$ in KBHECO1 and $17.13 \pm 1.58$ in KBHEC10), in the form of cassiterite crystals $\left(\mathrm{SnO}_{2}\right)$, highlighted by X-Ray diffraction and performed on a sample of white glaze from the above samples.

It is also possible that the unmelted quartz crystals in the white glaze reinforce the effect of the tin oxide in the opacification phenomenon. Indeed, we know that the opacity of the pre-Islamic glazes is sometimes related to the only presence of quartz crystals and feldspar (Mason, 1997).

We also observe the presence of iron in non-negligible content $\left(\mathrm{Fe}_{2} \mathrm{O}_{3}=2.55 \%\right.$ for $\mathrm{KBHECO1}$ and $4.49 \%$ for KBHEC10), which may explain the white color with a yellow tendency of glazes contained in the two samples, because $1 \%$ of iron oxide is enough to dimly dye a glaze. Besides, this high content in iron could also come from an intentional addition of it, in order to change few properties of the glaze. Sometime a matt glaze will get bright and shiny by adding 2 to $3 \%$ of iron (Picon, 1973). But the presence of lime in high content $(05.56 \%$ in $\mathrm{CaO})$ minimized the effect of the iron oxide on the glaze's color.

On the other hand, the non-negligible content in aluminum (4.40\% of $\mathrm{Al}_{2} \mathrm{O}_{3}$ for KBHEC10) could explain that there was an intentional addition of aluminum as well, as alumina increases the viscosity of the glaze and the adhesion to the ceramic substrate.

The elementary analysis of the green glazes from the KBHEC08, KBHEC09 and KBHEC12 samples (Table 1) show that they are leaded and that the tin (with the respective content of $\mathrm{SnO}_{2}=11.63 \%, 10.05 \%$ et $10.86 \%$ ) explains the opacification of the glazes.

Table 1. Qal'a of Bani Hammad. Elementary analysis by scattering energy X-Rays fluorescence, of the white and green glaze, converted in oxides mass percentage of studied samples. Nd : not determined.

\begin{tabular}{|c|c|c|c|c|c|}
\hline \multirow{2}{*}{ Oxides } & KBHEC01 & KBHEC10 & KBHEC 08 & KBHEC09 & KBHEC12 \\
\hline & White glaze & White glaze & Green glaze & Green glaze & Green glaze \\
\hline $\mathrm{SiO}_{2}$ & 51.32 & 32.77 & 36.44 & 21.57 & 23.93 \\
\hline $\mathrm{Al}_{2} \mathrm{O}_{3}$ & 01.72 & 04.40 & 04.43 & 01.26 & 03.15 \\
\hline $\mathrm{CaO}$ & 02.59 & 05.56 & 05.85 & 02.03 & 03.44 \\
\hline $\mathrm{MgO}$ & nd & 03.75 & 01.00 & 00.23 & 03.08 \\
\hline $\mathrm{Na}_{2} \mathrm{O}$ & 00.84 & 00.59 & 00.73 & nd & 00.85 \\
\hline $\mathrm{K}_{2} \mathrm{O}$ & 02.79 & 03.60 & 00.60 & 00.58 & 00.58 \\
\hline $\mathrm{PbO}$ & 25.49 & 23.46 & 26.91 & 27.79 & 22.77 \\
\hline $\mathrm{SnO}_{2}$ & 10.95 & 17.13 & 11.63 & 10.05 & 10.86 \\
\hline $\mathrm{Fe}_{2} \mathrm{O}_{3}$ & 02.55 & 04.49 & 01.74 & 04.23 & 01.46 \\
\hline $\mathrm{CuO}$ & nd & nd & 08.93 & 28.85 & 25.83 \\
\hline $\mathrm{ZnO}$ & nd & 00.90 & nd & nd & nd \\
\hline $\mathrm{P}_{2} \mathrm{O}_{5}$ & 01.74 & 00.34 & 00.45 & nd & nd \\
\hline $\mathrm{C}$ & nd & 03.02 & 01.29 & 03.11 & 04.05 \\
\hline $\mathrm{Cl}$ & nd & nd & nd & 00.30 & nd \\
\hline
\end{tabular}


The optical absorption spectra at the level of the glaze from the three samples revealed the presence of the $\mathrm{Cu}^{2+}$ ion as the chromogen agent responsible for the green color of these glazes, and the elementary analysis of the glaze confirm these data. The copper combined to the lead gives a green color when in an oxidizing atmosphere. Furthermore, the presence of iron in high content $\left(\mathrm{Fe}_{2} \mathrm{O}_{3}=04.23 \%\right)$ in the glaze of the KBHEC09 sample, leads us to believe that it was intentionally added in order to darken and deepen the green color coming from the copper oxide (28.58\% in $\mathrm{CuO})$, which resulting color is dark bottle-green.

Finally, it is important to point out the presence of carbon impurities, in all studied glazes, due to the preparation of the samples, which glazed surfaces were covered by a thin carbon layer.

\subsection{Nature of the terra cotta}

\subsubsection{Elementary analysis}

The results of the elementary analysis by X fluorescence, carried out on the terra cotta subsrate, are converted in weight oxides percentage (Table 2). The terra cotta of the whole samples is calcique, the content in $\mathrm{CaO}$ varies from 22.06 to $27.50 \%$. The calcium in high content reveals that the ceramicist used an earth rich in calcium or that he added it intentionally, according to some authors. A substrate rich in calcium would be the most suitable to receive leaded glazes, due to their distention coefficient and their high porosity, that facilitates the adhesion of the glaze. We also observe the presence of iron in non-negligible content (between 5.48 and $6.12 \%$ in $\mathrm{Fe}_{2} \mathrm{O}_{3}$ ); this element is almost always present in bedrocks. But, despite its presence, the color of the support contained in most of the samples remains light, certainly due to its calcique character (Maniatis, 1983).

\subsubsection{Crystallographic analysis}

By using the X-Ray diffraction (fig. 7), we highlighted the presence if the calcite $\left(\mathrm{CaCO}_{3}\right)$, of Quartz $\left(\mathrm{SiO}_{2}\right)$, Gehlenite $\left(\mathrm{Ca}_{2} \mathrm{Al}_{2} \mathrm{SiO}_{7}\right)$ and Albite $\left(\mathrm{Na} \mathrm{Al} \mathrm{Si}_{3} \mathrm{O}_{8}\right)$ in the paste contained in the studied samples (figure 9). Besides, we notice the presence of the aluminous Diopside, (Ca (Mg, $\left.\mathrm{Fe}, \mathrm{Al})(\mathrm{Si}, \mathrm{Al})_{2} \mathrm{O}_{6}\right)$, of the Wadalite $\left(\mathrm{Ca}_{6} \mathrm{Al}_{5} \mathrm{Si}_{2} \mathrm{O}_{16} \mathrm{Cl}_{3}\right)$ and the Basanite $\left(\mathrm{CaSO}_{4}\left(0.5 \mathrm{H}_{2} \mathrm{O}\right)\right)$ in the terra cotta of the KBHEC01 sample. Moreover, it is important to mention the presence of Gypsum in the KBHEC05 and KBHEC08 samples, as well as the Augite in KBHEC05, 06, 10 and 12 and the Orthose in KBHEC08 and 12.

Table 2. Qal'a of Bani Hammad. Elementary analysis by X-Ray fluorescence of the terra cotta, converted in oxides mass percentage of studied samples.

\begin{tabular}{|c|c|c|c|c|c|c|c|}
\hline Oxides & KBH01 & KBH05 & KBH06 & KBH08 & KBH09 & KBH10 & KBH12 \\
\hline $\mathrm{SiO}_{2}$ & 42.20 & 41.29 & 35.50 & 38.92 & 39.76 & 44.41 & 43.85 \\
\hline $\mathrm{Al}_{2} \mathrm{O}_{3}$ & 14.62 & 14.99 & 14.66 & 12.95 & 13.98 & 13.92 & 14.27 \\
\hline $\mathrm{CaO}$ & 24.71 & 22.06 & 27.50 & 26.84 & 24.32 & 22.94 & 23.61 \\
\hline $\mathrm{MgO}$ & 2.86 & 2.26 & 1.91 & 2.20 & 2.17 & 2.56 & 2.57 \\
\hline $\mathrm{Na}_{2} \mathrm{O}$ & 0.94 & 1.65 & 1.32 & 1.00 & 1.60 & 1.20 & 1.16 \\
\hline $\mathrm{K}_{2} \mathrm{O}$ & 1.02 & 1.61 & 0.83 & 0.88 & 1.52 & 1.13 & 1.26 \\
\hline $\mathrm{Fe}_{2} \mathrm{O}_{3}$ & 6.03 & 6.12 & 6.02 & 5.56 & 5.59 & 5.48 & 5.69 \\
\hline $\mathrm{TiO}$ & 0.85 & 0.85 & 0.87 & 0.76 & 0.80 & 0.79 & 0.80 \\
\hline $\mathrm{P}_{2} \mathrm{O}_{5}$ & 0.16 & 0.17 & 0.17 & 0.16 & 0.14 & 0.19 & 0.21 \\
\hline $\mathrm{S}$ & 0.32 & 1.00 & 1.93 & 0.73 & 0.39 & 0.54 & 0.40 \\
\hline $\mathrm{P.F}$ & 6.30 & 8.00 & 9.26 & 10.00 & 9.74 & 6.85 & 6.19 \\
\hline Total & 100 & 100 & 100 & 100 & 100 & 100 & 100 \\
\hline
\end{tabular}




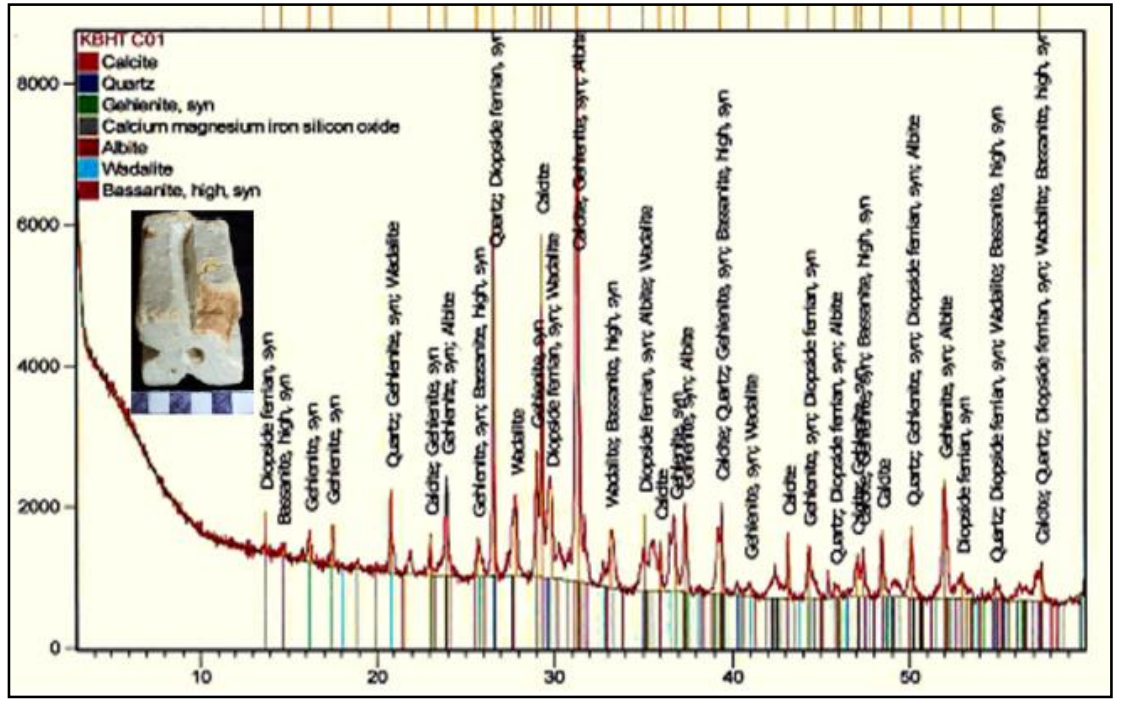

(a)

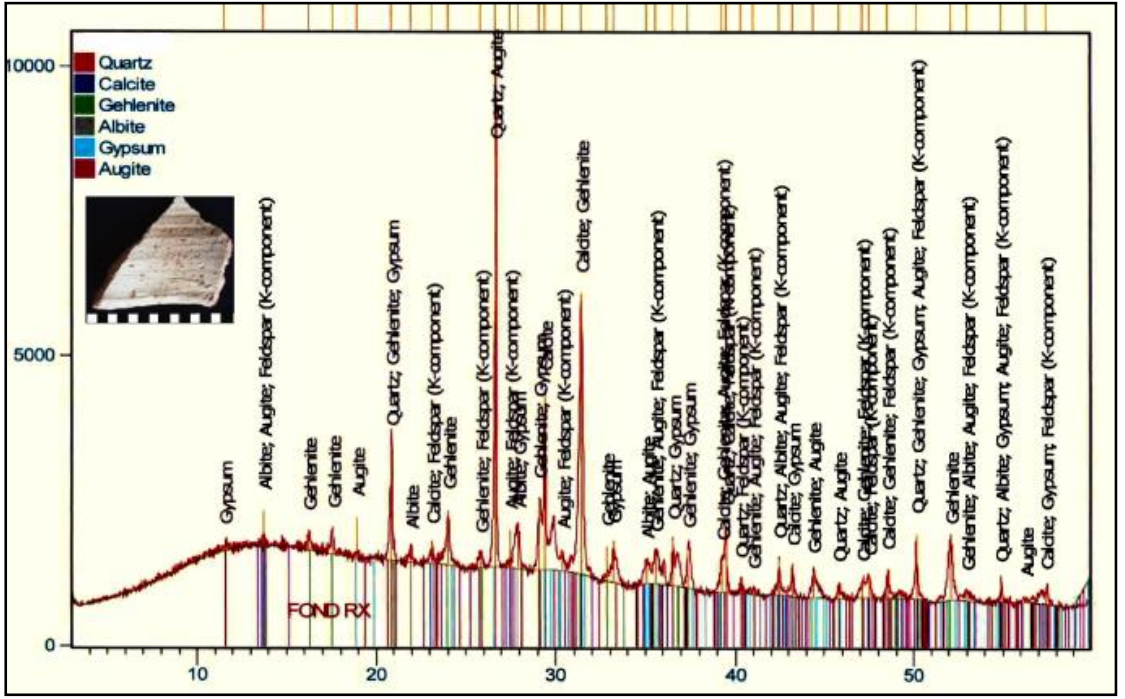

(b)

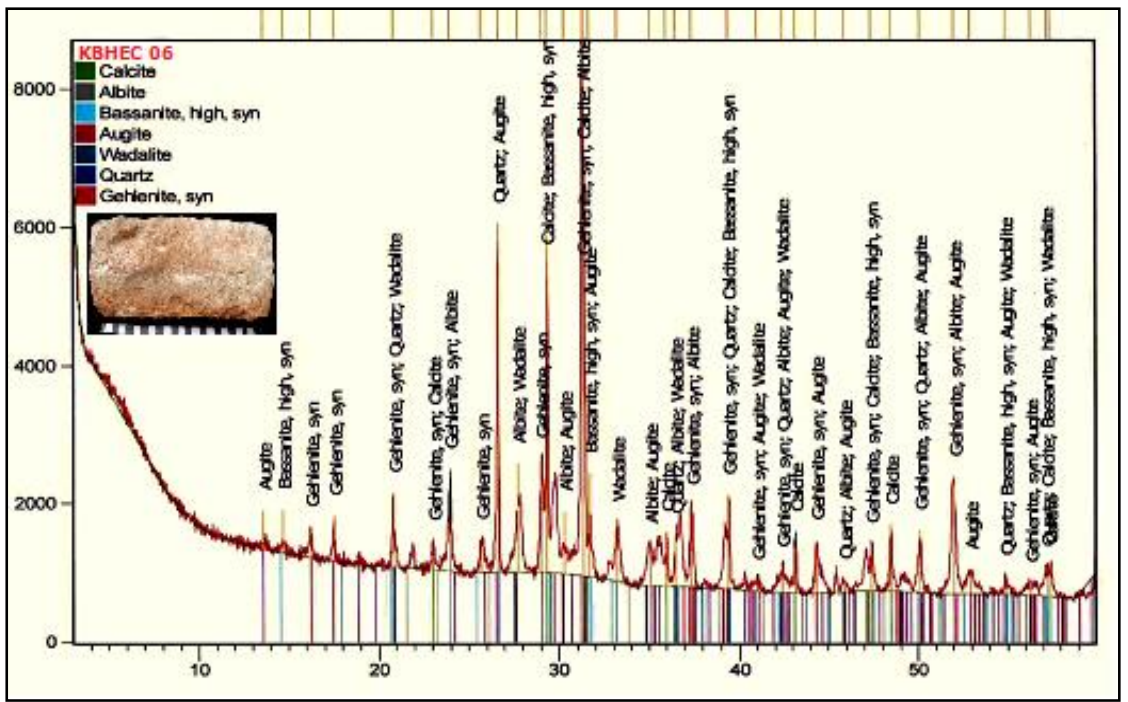

(c) 


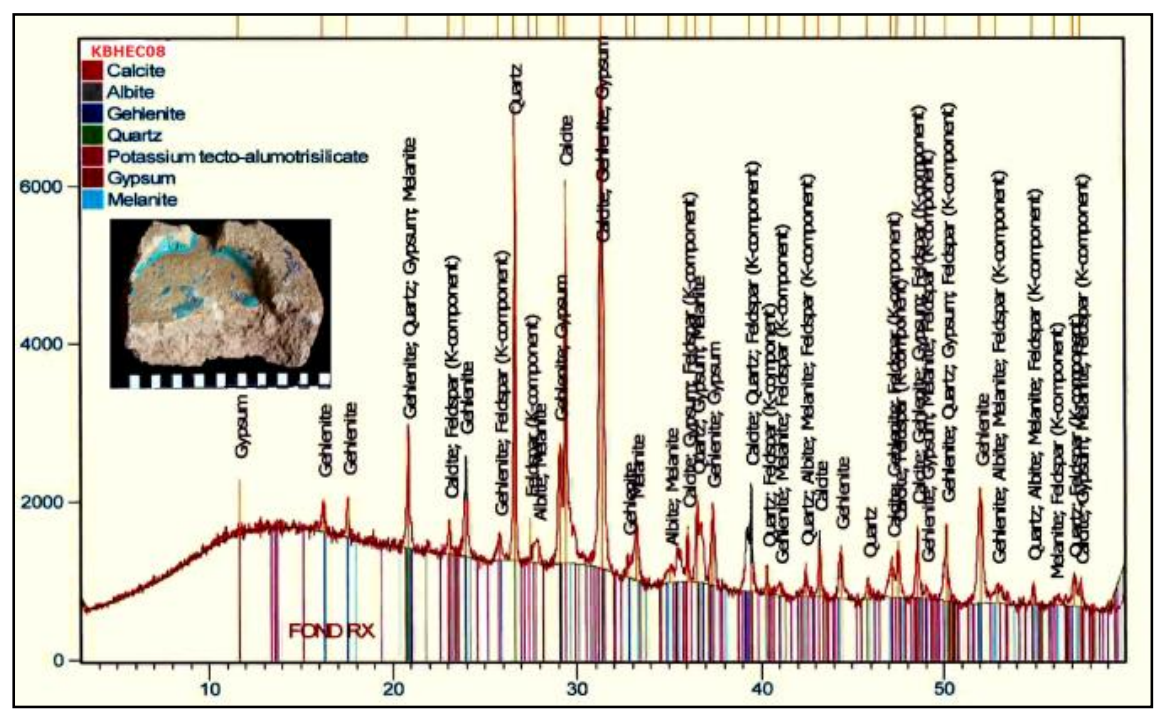

(d)

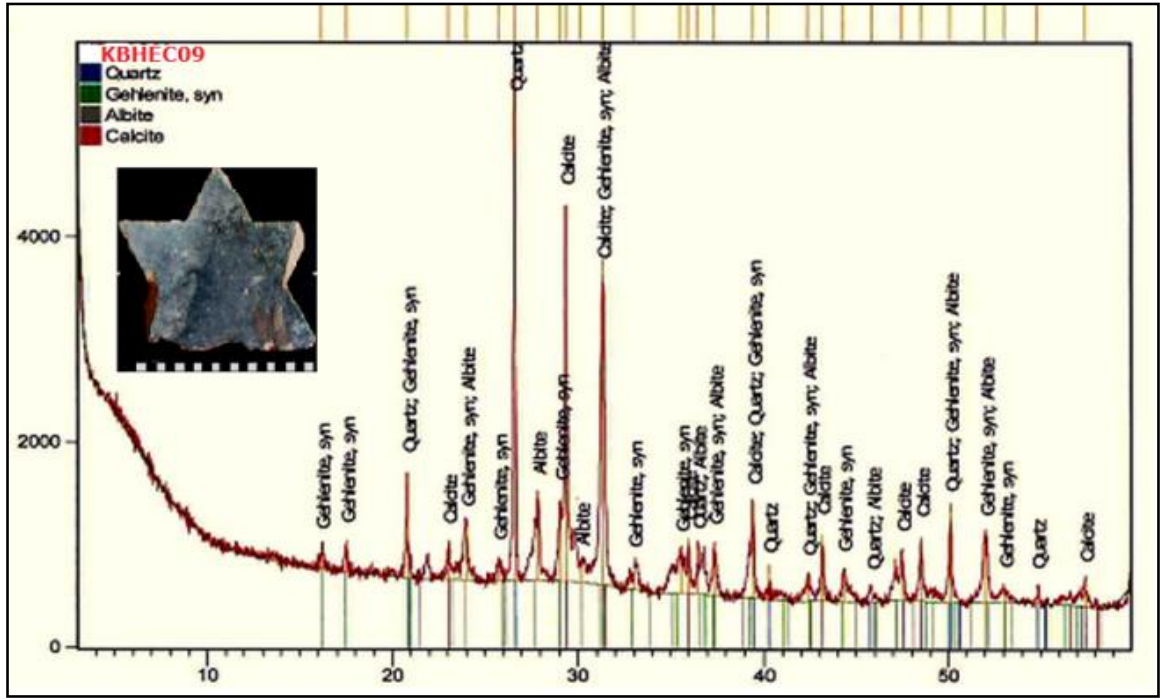

(e)

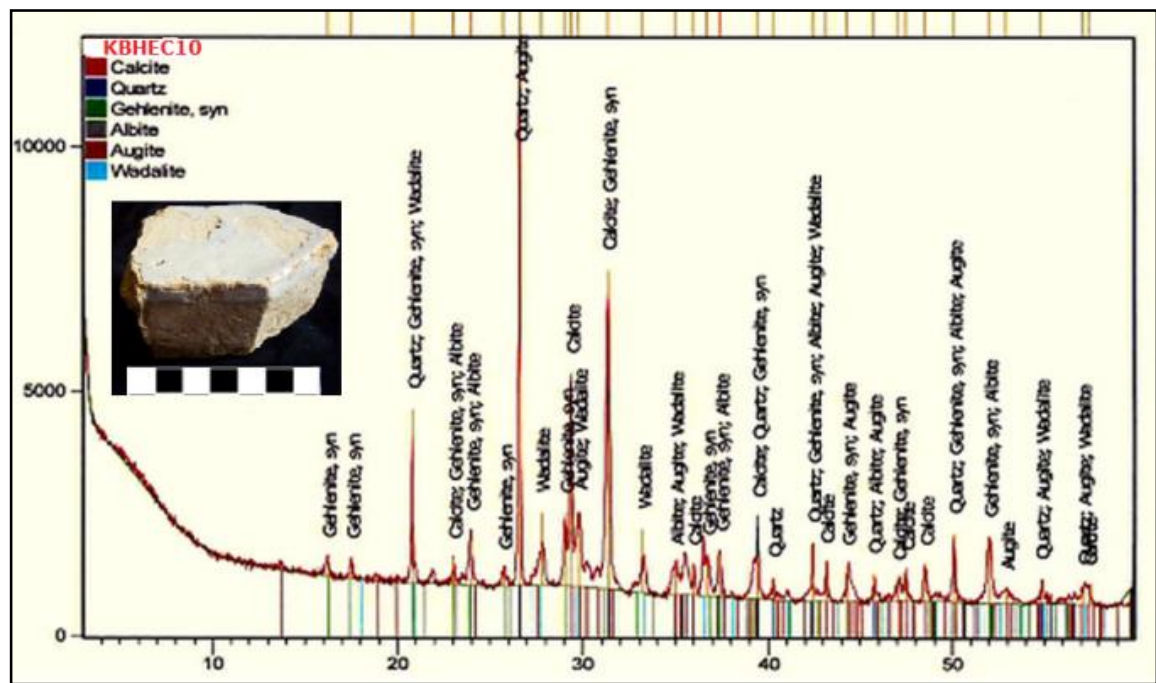

(f) 


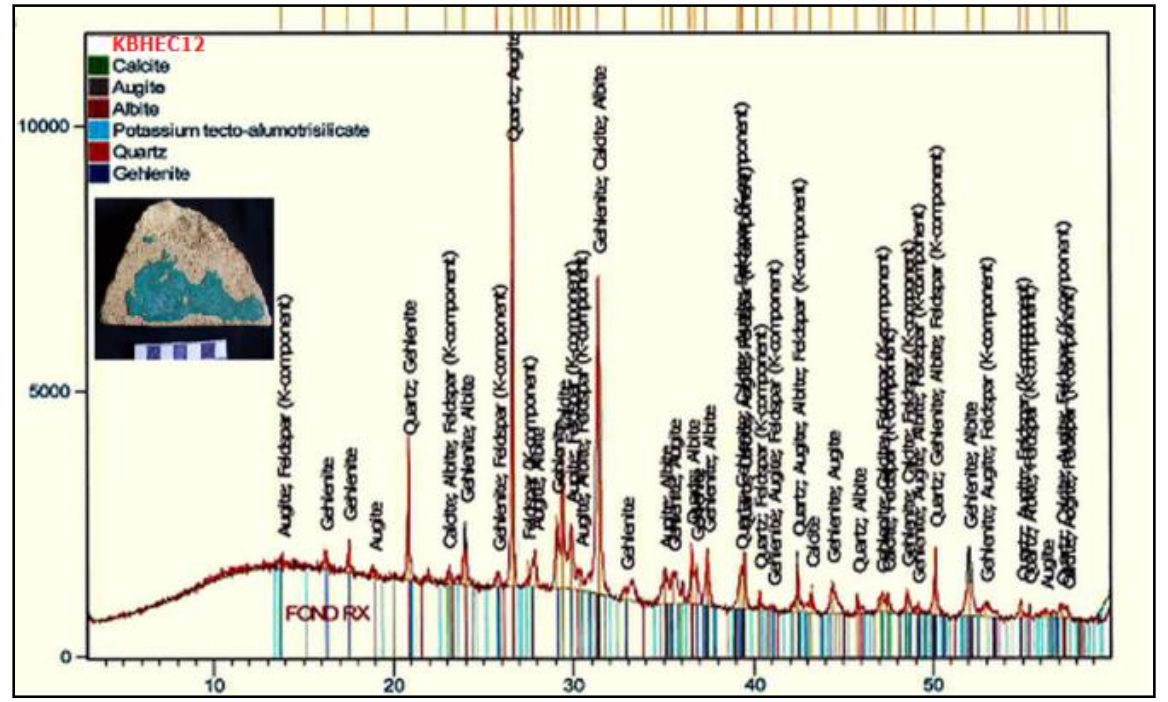

(g)

Fig. 7. Qal'a des Bani Hammad, X-Ray diffraction spectrum of terra cotta from the KBHEC01(a), KBHEC05 (b), KBHEC06 (c), KBHEC08 (d), KBHEC09 (e), KBHEC10 (f), KBHEC12 (g) samples.

The X-Ray diffraction enables us to highlight the mineralogical composition and thus, it is possible to define temperature zones. The Gehlenite (silico-aluminatecalcium) appears at about $800^{\circ} \mathrm{C}$ and reaches its maximum at around $900^{\circ} \mathrm{C}$. The cohesion of the limestone pastes results from the formation of the Gehlenite, when the baking does not exceed $900^{\circ} \mathrm{C}$. However, at the highest temperature the cohesion role is mainly played by the Anorthite. The Diopside is formed after the Gehlenite. But the fact that we discovered an important phase of unseparated calcite allows us to venture the hypothesis that the substrate would have been baked at around 850 to $900^{\circ} \mathrm{C}$ with a short length of baking time, which produced an incomplete separation of the calcite. It is important to mention as well that once baked, the shard shouldn't contain calcite. The separation tension of the calcite is about 1 atmosphere at $900^{\circ} \mathrm{C}$, but the separation becomes appreciable from $700^{\circ} \mathrm{C}$ in limestone clays (Picon, 1973).

Nevertheless, it is not rare to discover calcite in archaeological ceramics. There could be three reasons:

a- The baking temperature remained at a lower level to bring the complete separation of the calcite, from which a part remained unchanged.

b- The baking temperature, although it was high enough to lead to a complete separation of the calcite, was not maintained a sufficient time so the quicklime $(\mathrm{CaO})$ resulting from the decomposition of the carbonate $\left(\mathrm{CaCO}_{3}\right)$ could get mixed with the other constituents of the paste. In these conditions there will remain a certain proportion of lime in the shard. But this lime, sooner or later, will come back to a carbonate by fixing the carbonic gas $\left(\mathrm{CO}_{2}\right)$ of the air (Picon, 1973).

c- It results from a sediment (the action in a landfill place), which means that the calcite come from the water contained in landfill soils.

\section{Conclusions}

This study of characterization, that concerns few samples of architectural ceramic collected at the level of the Qal'a of Bani Hammad, enables us to know the nature of clays in this region better and to conclude that:

- The ceramic material updated at the Qal'a constitutes the major argument of a reasoning revealing the existence of an important handicraft of ceramic that developed in the area of this Hammadid site. 
- The similarity regarding the composition, between the samples of the analyzed ceramics, stipulates that the production workshops used the same baking method, which temperature can vary from 850 to $900^{\circ} \mathrm{C}$.

\section{References}

Aissani, D. \& Amara, A. (2014). Qal'a des Bani Hammād : première capitale du royaume berbère des Hammadides (XIe siècle), 97547_Enc_Berbere_05.ind.

Daoulatli, A. (1978). La céramique Ifriqiyenne du IXe au XVe siècle. Colloques Internationaux du C.N.R.S $\mathrm{N}^{\circ}$ 584--La céramique médiévale en méditerranée occidentale Xe-XVe siècles, Valbonne 11-14 septembre 1978, édition du C.N.R.S Paris, 1980, p 197- 201.

Golvin L. (1978). Les céramiques émaillées de période hammâdide Qal'a des Banû Hammâd (Algérie). Colloques Internationaux du C.N.R.S N584-La céramique médiévale en méditerranée occidentale Xe-XVe siècles, Valbonne 11-14 septembre 1978, édition du C.N.R.S Paris, 1980, p 203.

Maniatis, Y., Simopoulos, A., Kostikas, A. \& Perdikatsis, V. (1983). Effect of reducing atmosphere on minerals and iron oxides developed in fired clays: the role of $\mathrm{Ca}$, in Journal of the American ceramic Society, 66, 11, 1983, p. 773- 781.

Marçais, G. (1913). Les Poteries et Faïences de la Qal'aa des Beni Hammad XIe siècle ;Contribution à l'étude de la Céramique Musulmane, Constantine 1913. pp 4- 17.

Mason. R (1997). M.S. Tite - The beginnings of tin-opacification of pottery glazes, in Archaeometry, 39, 1, 1997, p. 41-58.

Munier. P (1957). Technologie des faïences, M.P.de Groote, France, 1957, p 25-209.

Picon, M. (1973). Introduction à l'étude des céramiques sigillées de Louzoux, Publié par Dessain et Tolra, Paris, 1973, P 16-73.

Rhodes, D. (1976). La Poterie, Terres et Glaçures : Les techniques de l'émaillage, Dessain et Tolra Paris, p 43-175.

Richard, S. (2000). Etude physique des Carreaux glaçurés du palais des Beys Alger XVIIe- XVIIIe siècle, sur la nécessité de connaître la texture et la nature des constituants (terre cuite, glaçure et décors en vue de recréations, mémoire de D.E.A de l'Université de Michel de Montaigne- Bordeaux 3, p16106. 